\title{
CROP DIVERSIFICATION, PRODUCTIVITY AND DIETARY DIVERSITY: A GENDER PERSPECTIVE
}

\author{
Adekemi OBISESAN *, (iD David AWOLALA (iD)
}

\begin{abstract}
Address:
Federal University of Technology, Akure, School of Agriculture \& Agricultural Technology, Department of Agricultural \& Resource Economics, P.M.B. 704, Akure, Ondo State, Nigeria

* Corresponding author: kemi triumph@yahoo.com
\end{abstract}

\begin{abstract}
Research background: Strengthening agriculture and food systems have a critical role to play in achieving the sustainable development goals of eliminating hunger and poverty; and increasing resilience to climatic shocks. Crop diversification has been recognized as a way of increasing resilience and reducing agricultural risk. Closing the gender gap could boost agricultural productivity and enhance welfare. Effects of crop diversification in enhancing dietary diversity amidst gender gap in agricultural productivity among smallholders have not been well established in Nigeria. Purpose of the article: The study was conducted to provide empirical evidence on crop diversification, productivity and dietary diversity of male and female-headed farming households in Nigeria. This has policy implications on development of inclusive and efficient agrifood system towards achieving the SDGs of eradicating poverty, hunger and gender equality.

Methods: Secondary data from the 2015/16 Living Standard Measurement Survey-Integrated Survey on Agriculture (LSMS-ISA) was used for this study. Tobit regression model was employed to investigate the factors influencing crop diversification and dietary diversity while Oaxaca-Blinder decomposition method was used to decompose gender differentials in agricultural productivity.

Findings and value added: Crop diversification index of male farmers is $0.10(\mathrm{P}<0.05)$ higher than female farmers. The Tobit regression results showed that farm income, education, household size, farm size and use of inorganic fertilizer increased crop diversification $(\mathrm{P}<0.01)$. However, household expenditure $(\mathrm{p}<0.05)$, non-farm income $(\mathrm{p}<0.1)$, age and credit access $(\mathrm{P}<0.01)$ reduced crop diversification. Less than half $(45.22 \%)$ of the rural households consumed at least nine out of the 12 food groups in the previous week of the survey period. Crop diversification among other factors has a positive $(\mathrm{P}<0.01)$ effect on households' dietary diversity. The results of the Oaxaca-Blinder decomposition showed a gender productivity gap of $10.87 \%$ in favour of male farmers. The structural and endowment disadvantages of female farmers in land size and credit access are key drivers of gender differentials in agricultural productivity. The study suggests improvement in land tenure system and female farmers' access to financial services in order to ensure gender productivity equality, women empowerment and efficient agrifood system.
\end{abstract}

Key words: Agrifood; Food Security; Gender equality; Inclusive; Resilience JEL Codes: R52; R58; H41

\section{INTRODUCTION}

Agriculture is a significant value-added contributor to the national food self-sufficiency in most rural developing economies which account for over $90 \%$ of total food consumption requirements. The sector has been recognized as an established pathway to prosperous economy (Alliance for a Green Revolution in Africa (AGRA), 2017). Nonetheless, there is higher growthpoverty elasticity for agricultural development than nonagriculture although the extent varies across countries considerably (Christiaensen and Martin, 2018; Dorosh and Thurlow, 2016; Christiaensen and Demery, 2007). In Africa, over $70 \%$ of the population depends on agricultural foods and income-based livelihoods such that agriculture-sector growth is a significant driver in achieving the Sustainable Development Goals (SDGs) 1 and 2 of eradicating poverty and hunger, respectively. Despite the fundamental objective of SDG 2 to end hunger, achieve food security and improved nutrition and promote sustainable agriculture by 2030 , it is however, a developing burden still that with about a decade left to meet the targets, multiple countries especially in the subSaharan Africa (SSA) presently record higher levels of hunger than in 2010 (von Grebmer et al., 2019). This situation has been attributed to poverty, inequality and ravaging effects of climate factors, among other factors.

Africa is well endowed with a resource base that is capable of turning the continent into a net large agricultural exporter, if more intensively farmed. This potential is evidenced by reduced yield currently experienced in Africa compared with continents with 
similar agro-ecological Zones and best practices (Jistrom, Andersson and Djufeldt, 2011; Food and Agriculture Organization (FAO) et al., 2017). Adesina (2017) expressed that Africa is more dependent on food import, for instance, Nigeria's aggregate annual food import bill is expected to increase from US $\$ 35$ billion to above US $\$ 110$ billion by 2025 . Furthermore, the SSA has the world's lowest agricultural productivity attributed to high poverty level which implies that household's access to food is constrained by poor own production and low purchasing capacity (World Bank, 2019).

It is important to strengthen agriculture and food systems at local scale in order to achieve the SDGs targets of eliminating hunger and poverty; and enhances resilience to climatic shocks. The sub-Sahara can overcome the challenge of meeting its 2050 Food Security Agenda should millions of smallholder engaged in productivity-enhancing strategies (Herrero et al., 2017, Dioula et al., 2013). Crop diversification has been recognized as a way of increasing resilience and reducing agricultural risk especially among smallholders. This strategy enhances biodiversity and yield stability, improves soil fertility, controls pests and diseases, and capable of positive effects of farming households' welfare (Di Falco and Chavas, 2009; Lin, 2011; Bezabih and Sarr, 2012; Njeru, 2013). Crop diversification is fashioned as a way of developing climate resilient agricultural system, reducing food and nutrition insecurity, especially in the rural areas as more diverse production system could contribute to more diverse diets for farming households.

Food insecurity keeps rising in Nigeria regardless of abundant human resources, natural capital, agricultural programmes, and interventions. The country ranks $94^{\text {th }}$ of the 113 countries with food security index score of 48.4 (The Economists, 2020). This rank is due to declining agricultural productivity. Dietary parameters further reveals that about $37 \%$ of Nigerian children are stunted, $29 \%$ are underweight, and $18 \%$ are wasted. The country's Global Hunger Index (GHI) score rose from 15.5 in 2011 to 25.5 in 2015 then to 27.9 in 2019 reflecting a serious hunger situation (von Grebmer et. al., 2019). Majority of the undernourished people live in rural areas and are predominantly smallholder farmers. Hence, the consideration of making agriculture and food systems more nutrition-sensitive is of great importance for agricultural development and policy.

Gender bias in agriculture is crucial to sustaining economic growth and ensuring food security, particularly in countries where most of the populations earn their incomes from agriculture-based activities (Bizzari, 2017; Mukasa and Salami, 2016; Kenan, 2014; Deschutter, 2013). Thus, closing the gender gap could boost agricultural productivity and income by ensuring equality in access to productive resources in raising agricultural output in developing countries and help reduce hunger (Giroud and Huaman, 2016). International Food Policy Research Institute (IFPRI) (2019) opined that agricultural growth and sustainability further hinges on addressing gender inequality. Inequalities make it more difficult to achieve better productivity, reduce poverty and hunger. For instance, in countries where incomes are highly unequal between female and male wages, lower levels of land productivity and higher food insecurity have been witnessed, on the average. These inequities are slowing progress towards SDG 2. The discriminating factors generally encompass land constraints, property rights, low application of modern resources, limited access to advisory services, low stocks of human and physical capital and exclusion from credit and financial markets (Backiny-Yetna and McGee, 2015; Ali et al., 2015; Aguilar et al., 2014). There is a very strong positive linear correlation between socio-economic variables and gender inequality. It was concluded that gender inequalities is very high in the Nigerian agricultural sector and it is hampering economic growth (Ijieh et al., 2015).

Oseni et al. (2014), Aguilar et al. (2014), BackinyYetna and McGee (2015) and Mukasa and Salami (2015) previously analysed gender differentials in agricultural productivity in Nigeria, Ethiopia, Niger and Nigeria respectively. These studies measured productivity in monetary values, and considered farm plot managers. However, our study employed 2015/16 LSMS-ISA dataset to measure land productivity in terms of crop yield (kg/hectare) and considered farming households. This approach was moved by the assumption that household heads are mainly responsible for their economic wellbeing, the gender of the households' head affects the manner in which households' resources are utilized and disbursed, and the manner in which households are networked for exchange of resources with other households. Furthermore, it removes the problem of misidentification in the households and overlaps along gender lines (Gebre et al., 2019; de la O Campos et al., 2016; Lloyd and Gage-Brandon, 1993). Nevertheless, effects of crop diversification in enhancing dietary diversity have not been well established in Nigeria.

This study investigates effect of crop diversification on dietary diversity amidst gender gap in agricultural productivity among smallholders in Nigeria. This study complements previous studies on gender differentials in agricultural productivity in Nigeria with policy implications on development of inclusive and efficient agrifood system towards achieving the SDGs of eradicating poverty and hunger and gender equality. Arising from the foregoing, the general objective of this study is to investigate gender inequality in crop diversification, productivity and dietary diversity among farming households in rural Nigeria. The specific objectives are to: Estimate crop diversification index and identify the socioeconomic factors influencing crop diversification among male and female headed households in Nigeria; Estimate dietary diversity of male and female headed households; Examine the effect of crop diversification and other socio-economic factors on dietary diversity of Nigerian households and Investigate gender differentials in agricultural productivity among Nigerian farming households.

\section{LITERATURE REVIEW}

Studies have observed that farmers can achieve resilient agricultural systems that contribute significantly to household food security through crop diversification (Ojo 
et al., 2014; Makate et al. , 2016; Rajendran et al., 2017; Mango et al. , 2018). The literatures emphasized crop diversification as a means of overcoming the adverse effect of weather shocks and climate change. These studies have also drawn attention to range of socioeconomic and institutional factors affecting crop diversification and dietary diversity among small-holder farmers in Africa. For instance, Ojo et al. (2014) opined that farming experience, extension contact, farm size and land ownership positively and significantly affected diversification among farmers. Crop diversification had positive and significant effect on food crop outputs. According to Sichoongwe (2014), landholding size, fertilizer quantity, distance to market, and the type of tillage mechanism adopted have a strong influence on crop diversification in Zambia. The studies suggest the need for government to consider undertaking policies that will enhance farmers' access to and control over land. Furthermore, households that diversify their crop production tend to increase their food consumption and dietary diversity (Rajendran et al., 2017; Mango et al., 2018). In Central Malawi, Mango et al. (2018) asserts that crop diversification, cattle ownership, access to credit and attainment of education have positive and significant effect on the households' food consumption score.

Decomposition methods have been employed to analyze differences in agricultural productivity between male and female land managers in Africa (Aguilar et al., 2014; Oseni et al., 2014; Backiny-Yetna and McGee, 2015; Mukasa and Salami, 2015). The Oaxaca-Blinder decomposition method allows for decomposing the unconditional gender gap into (i) the portion caused by observable differences in the factors of production (endowment effect) and (ii) the unexplained portion caused by differences in returns to the same observed factors of production (structural effect) or (iii) even in differences in both the levels and returns of these observables (interaction effect). This methodology identifies the factors that explain productivity gap both at the aggregate and detailed levels. Analysis along the productivity distribution reveals that gender differentials are more pronounced at mid-levels of productivity and that the share of the gender gap explained by the endowment effect declines as productivity increases (Aguilar et al., 2014). Most studies have observed that women have access to less productive resources and plots managed by women produce less than plots managed by men (Oseni $\boldsymbol{e t}$ al., 2014; Backiny-Yetna and McGee, 2015; Mukasa and Salami, 2015). Endowment and structural disadvantages of female managers in land size, land quality, labor inputs, and household characteristics are the main drivers of gender gaps. However, closing gender productivity differentials is expected to yield production gains, to raise monthly consumption and to help households with female-managed lands climb out of poverty in Africa (Mukasa and Salami, 2015).

Despite the previous studies, there is still paucity of information on crop diversification and dietary diversity among rural households in Nigeria. Also, there is limited information on gender differentials in agricultural productivity based on the 2015/16 LSMS-ISA data set. Therefore, this study contributes towards bridging the gap and complements previous studies on crop diversification and dietary diversity in Nigeria by using a nationally representative data. The study examines progress in closing gender gaps in agricultural productivity by using the 2015/16 LSMS-ISA dataset. Furthermore, unlike previous studies, it considers the households instead of plot managers in investigating gender differentials in agricultural productivity.

\section{DATA AND METHODS}

\section{Data}

The study used secondary data from the 2015/16 Living Standard Measurement Survey-Integrated Survey on Agriculture (LSMS-ISA) which comprises 5,000 rural and urban households in Nigeria. This study focuses on the rural households' aspect of the data, given that the rural sector harbors the highest percentage of farm families where agricultural livelihood is predominant. The data comprises 3,172 rural households, however, due to the incompleteness of the data, data on 1,226 maize farming households were used for analysis. The data used for the study include socio-economic/demographics such as: age, sex, household size, farm size, credit access, education, income, farm size, income sources, crops production and income, among others.

\section{Methods of data analysis}

The analytical techniques employed in this study include descriptive statistics, Z-test, Tobit regression model and Oaxaca-Blinder (OB) decomposition. Descriptive analysis was used in estimating crop diversification while Tobit regression model was used to examine major drivers of crop diversification among smallholders. Crop diversification index was computed indicating whether a farmer cultivates more than one crop or not. A zero value would indicate specialization, revealing a farmer's decision to cultivate only one food crop while a value greater than zero shows crop diversification, conditioned on choice, explaining the intensity of diversification. It is therefore easy to identify those farming households practicing crop diversification, and intensity of their diversification.

Tobit regression model is a censored regression model which captures both the propensity to diversify and the intensity of diversification, hence most appropriate for this study (McDonald, 1980).

Tobit regression model was used to analyse factors influencing food crop diversification, following Maddala, (1992); Johnston and Dandiro, (1997) and Negash, (2007), the Tobit model for the continuous variable decision level can be expressed as Eq. 1.

$$
\begin{aligned}
& Y_{i}=Y_{i}^{*}=\beta_{0}+\beta_{i} X_{i}+\mu_{i} \text { if } Y_{i}^{*}>0 \\
& Y_{i}=0 \text { otherwise }
\end{aligned}
$$

Where:

$Y_{i}^{*}$ Latent variable and solution to utility maximization problem of level of crop diversification, subject to a set of constraints per household;

$Y_{i}$ Crop diversification index for an $\mathrm{i}^{\text {th }}$ farmer;

$X_{i}$ Vector of factors affecting crop diversification; 
$\beta_{i}$ Vector of unknown parameters;

$\mu_{i}$ Error term.

The explanatory variables specified as determinants of crop diversification are defined as:

$X_{1} \quad$ Sex (female $=1,0$ otherwise); $X_{2}$ Age (years); $X_{3}$ Education (years); $X_{4}$ Household size (number); $X_{5}$ Selfemployment income (1= self-employed, 0 otherwise); $X_{6}$ Agricultural wage employment (1= yes, 0 otherwise); $X_{7}$ Farm size (hectare); $X_{8}$ Credit access ( $1=$ yes, 0 otherwise); $X_{9}$ Extension service access ( $1=$ yes, 0 otherwise); $X_{10}$ Improved seeds cultivation ( $1=$ yes, 0 otherwise); $X_{11}$ Use of inorganic fertilizer (1= yes, 0 otherwise); $X_{12}$ Labour (Man-days); $X_{13} \quad$ Crop yield (kg/ha); $X_{14}$ Production costs (Nigerian currency Naira NGN); $X_{15}$ Crop income (NGN); $X_{16}$ Total income $(\mathrm{NGN}) ; X_{17}$ Commercialization index.

\section{Estimating dietary diversity and crop diversification effect}

Dietary diversity is a quantitative measure of food consumption that reflects household access to a variety of food. The household dietary diversity score was generated based on the number of different food groups consumed over a given reference period ( 7 days in the case of this study). This was constructed based on the 12 food groupings from the FAO's food balance sheet: cereals, roots/tubers, pulses/legumes, dairy, eggs, meat, fish and sea foods, oils and fats, sugar/honey, fruits, vegetables and other foods (FAO, 2011). The effect of crop diversification on dietary diversity was captured by applying Tobit regression which controls for variables such as individual, household, and institutional characteristics, etc. Tobit regression model for the continuous variable can be expressed as Eq. 2 .

$Y_{i}=Y_{i}^{*}=\beta_{0}+\beta_{i} X_{i}+\mu_{i} \quad$ if $Y_{i}^{*}>0$

$Y_{i}=0$ otherwise

Where,

$Y_{i}^{*}$ Latent variable and solution to utility maximization problem of level of dietary diversity, subjected to a set of constraints per household;

$Y_{i}$ Dietary diversity for an $\mathrm{i}^{\text {th }}$ household;

$X_{i}$ Vector of factors affecting dietary diversity;

$\beta_{i}$ Vector of unknown parameters;

$\mu_{i}$ Error term.

The explanatory variables specified as determinants of dietary diversity are defined as:

$X_{1}$ Sex (female $=1,0$ otherwise); $X_{2}$ Age (years); $X_{3}$ Education (years); $X_{4}$ Household size (number); $X_{5}$ Selfemployment income ( $1=$ self-employed, 0 otherwise); $X_{6}$ Agricultural wage employment (1= yes, 0 otherwise); $X_{7}$ Farm size (hectare); $X_{8}$ Credit access ( $1=$ yes, 0 otherwise); $X_{9}$ Extension service access (1= yes, 0 otherwise); $X_{10}$ Improved seeds cultivation ( $1=$ yes, 0 otherwise); $X_{11}$ Use of inorganic fertilizer (1= yes, 0 otherwise); $X_{12}$ Labour (Man-days); $X_{13}$ Crop yield (kg/ha); $X_{14}$ Production costs (NGN); $X_{15}$ Crop income (NGN); $X_{16} \quad$ Total income (NGN); $X_{17}$ Commercialization index; $X_{18}$ Crop diversification index.

\section{Gender differentials in productivity}

Following Kilic et al. (2013), Aguilar et al. (2013), Oseni et al. (2014), Backiny-Yetna and McGee (2015) and Mukasa and Salami (2015), Oaxaca-Blinder decomposition was employed to decompose gender differentials in agricultural productivity.

Let $y$ be the natural log of crop yield per unit land ( $\mathrm{kg} / \mathrm{ha}$ as measure of productivity), $g$ the gender of the farmer, and $x$ a $K+1$ dimension vector including the set of covariates of farming household's characteristics, farm size, inputs used etc.

The determinants of agricultural productivity can then be modelled using the following production function (Eq. 3).

$y=\sum_{j=0}^{k} \alpha_{j} x_{j}+\beta_{g}+\mu$

Where $\alpha_{j}$ and $\beta$ are unknown parameters to be estimated and $u$ is a random error term assume to be independently and identically distributed with mean zero and $\sigma^{2}$ variance. The presence of gender productivity gap can then be assessed by checking the significance of the coefficient $\beta$ in Equation (3). A negative and significant estimated coefficient indicates productivity differential at the expense of female-headed households and vice versa. Equation (3) was also estimated separately for male and female-headed households to identify any significant differences in the impact of various covariates on agricultural productivity. This approach helps to isolate the impact of the gender of the household head on the level of agricultural productivity after controlling for differences in other observed characteristics.

However, due to inability of this model to identify the fundamental drivers of productivity differences between male and female headed households, a decomposition procedure is necessary. This helps clarify whether the estimated productivity gaps are due to differences in the levels of observable characteristics between male and female-headed households (endowment effect) or due to the differences in the returns of these characteristics between both groups (structural effect), or even in differences in both the levels and returns of these observables (interaction effect). The decomposition starts with Equation (3) which is estimated for the pooled sample as well as by gender of the household heads as in Eq.4.

$y_{g}=\sum_{j=0}^{k} \alpha_{g j} x_{g j}+\mu_{g}$

With $g=\{m ; f\}$ and $\mu_{g}$ is the gender-specific random error term assumed independently and identically distributed, with mean 0 and variable $\sigma^{2}$. The rationale behind the $\mathrm{OB}$ decomposition approach is therefore to show how much of the mean productivity difference, $E\left(y_{m}\right)-E\left(y_{f}\right), E\left(y_{m}\right)$ and $E\left(y_{f}\right)$ denoting the expected values of agricultural productivity by male and female headed households, is accounted for by gender differences in the levels and returns of covariates X. Following Daymont and Andrisani (1984) and Jann (2008), the gender productivity differential $\mathrm{G}$ can also be written as Eq. 5. 
$G=E\left(y_{m}\right)-E\left(y_{f}\right)=\left[E\left(X_{m}\right)-E\left(X_{f}\right)\right] \beta_{f}+$

$E\left(X_{f}\right)\left(\beta_{m}-\beta_{f}\right)+\left[E\left(X_{m}\right)-E\left(X_{f}\right)\right]-\left(\beta_{m}-\beta_{f}\right)$

According to Equation (5) gender productivity differential can be explained by three factors:

i. Differences between male and female managers in the levels of observable covariates $X$. Accordingly, the first component in Equation (5), $\left[E\left(X_{m}\right)-E\left(X_{f}\right)\right] \beta_{f}$ gives the proportion of the estimated productivity gap explained by male and female differences in the levels of those covariates and is called the endowment effect.

ii. Differences in the returns of the covariates $X$. The second term, $E\left(X_{f}\right)\left(\beta_{m}-\beta_{f}\right)$ called the structural or coefficient effect, measures the part of the productivity differential attributable to differences in the returns of covariates (including the estimated coefficient of the intercept).

iii. Finally, the last component, $\left[E\left(X_{m}\right)-E\left(X_{f}\right)\right]-$ $\left(\beta_{m}-\beta_{f}\right)$ the interaction effect, captures the portion of productivity gap coming from simultaneous differences in both the predictors and their estimated coefficients. A positive value of the second component will imply that male headed households will have a structural advantage over female headed households in regards to the specific covariate while a negative value suggests a female structural advantage. The same reasoning holds for the other partial effects in Equation (5).

\section{RESULT AND DISCUSSION}

\section{Descriptive analysis of socio-economic profile of the respondents}

The gender-disaggregated descriptive results on Table 1 observe that male-headed households dominated the distribution by $84.99 \%$. The average age of the household heads is 53.09 years across both gender with an average of 4.67 years of schooling, and about 8 household members. These differ significantly between Female-Headed Households (FHH) and Male-Headed Households (MHH) as indicated that farm size of male-headed households is significantly $(p>0.05)$ higher than that of the female headed households by 0.77 hectares. Few households have access to formal credit services while the adoption of improved seeds is similar between $\mathrm{MHH}$ and $\mathrm{FHH}$. Further results show that there is no significant difference in the use of improved seeds between the two groups. In overall, about $57 \%$ of the respondents use inorganic fertilizers. The number is higher for MHH than FHH. In the same vein, total labour used on farm by MHH is significantly higher than FHH. Likewise, households' incomes generated from various sources by MHH was also found to be significantly higher than $\mathrm{FHH}$ incomes.

\section{Crop diversification and its determinants}

Over half of the respondents cultivated more than one crop while $47 \%$ specialized on a single crop. Farm income was significantly higher among farmers that diversified their crop production. The Crop Diversification (CD) index was 0.42 . The crop diversification index of male farmers was 0.10 significantly $(\mathrm{P}>0.05)$ higher than females' as expressed in Table 2. The results of the Tobit estimates on the determinants of crop diversification showed that nine of the seventeen variables included in the model significantly influenced the extent of crop diversification. Household size, crop income, farm size, total household income, extent of commercialization, crop yield and use of inorganic fertilizer increase crop diversification significantly while age and sex of household heads significantly reduce crop diversification as observed in Table 3. From the results, a unit increase in age of household head will reduce crop diversification by 0.0018 , hence as farmers' advance in age, they tend to specialize on production of a particular crop based on their long production experiences. Farmers' risk bearing capacity was also found to reduce as age increases which support previous findings of Ojo et al. (2014) that farmers' age negatively influences CD in North-Central Nigeria. Farm size was found to have positive and significant effect on $\mathrm{CD}$ which indicates that access to land resources gives room for easy practice of $\mathrm{CD}$ which also agrees with findings from Rahman and Chima (2016), Sichoongwe et al. (2014) and Benin et al. (2004) that farm size has significant and positive effect on CD in Southeastern Nigeria, Zambia and Ethiopia respectively.

A gender outlook further explained that belonging to a FHH reduces the extent of crop diversification significantly at $1 \%$. Thus, male farmers are more diversified in crop production than their female counterparts. This is evidently supported by more male farmers' access to agricultural production resources than females which enhanced their extent of diversification. This result is consistent with Dube (2016) findings that having a male household head increased crop diversification in Manicaland and Masvingo provinces in Zimbabwe. Application of inorganic fertilizer has positive and significant influence on CD. Fertilizers are important input in crop production which improves soil fertility for high yield. Although costly, the costs can be offset by high yields. This agrees with the findings of Sichoongwe $\boldsymbol{e t}$ al. (2014) that the quantity of fertilizer used increased the probability of engaging in crop diversification in Southern province, Zambia. Differences were observed in the correlates of CD between $\mathrm{MHH}$ and FHH. All the nine significant variables were found to influence $\mathrm{CD}$ among MHH but only three namely farm size, use of inorganic fertilizer and extent of commercialization were found to significantly influence CD among FHH.

\section{Effect of Crop Diversification on Dietary Diversity}

The study found that less than half $(45.22 \%)$ of the rural households consumed at least nine of the 12 food groups in the previous week of the survey period. The mean dietary diversity index of the households is 0.71 . The results in Table 4 further shows that diet is more diverse among $\mathrm{FHH}$ than $\mathrm{MHH}$ with a significant difference of 0.06 which implies that FHH spend more on high quality foods than MHH. 
Table 1: Descriptive statistics and mean differences tests by gender of household heads

\begin{tabular}{|c|c|c|c|c|c|}
\hline Variable & Definition & Pooled & FHH (\%) & MHH (\%) & Difference \\
\hline$\overline{\text { Age }}$ & Age of the household head (Years) & 53.09 & 57.60 & 52.15 & $5.45 * * *$ \\
\hline Education & $\begin{array}{l}\text { Household head's education (Years } \\
\text { of schooling) }\end{array}$ & 4.67 & 3.59 & 4.86 & $1.27 * * *$ \\
\hline Extension contact & $\begin{array}{l}\text { Household reached by extension } \\
\text { services (Number) }\end{array}$ & 14.03 & 3.80 & 15.83 & $12.03 * * *$ \\
\hline Household size & Total household size (number) & 7.82 & 5.74 & 8.11 & $2.59 * * *$ \\
\hline Farm size & Total farm size cultivated & 0.99 & 0.52 & 1.29 & $0.77 * *$ \\
\hline $\begin{array}{l}\text { Access to formal } \\
\text { credit }\end{array}$ & $\begin{array}{l}\text { Dummy }=1 \text { if respondent has access } \\
\text { to formal credit }\end{array}$ & 27.57 & 34.24 & 26.39 & $7.84 * * *$ \\
\hline Improved seeds & $\begin{array}{l}\text { Dummy }=1 \text { if respondent cultivated } \\
\text { improved varieties }\end{array}$ & 19.33 & 16.30 & 19.87 & 3.06 \\
\hline Inorganic fertilizers & $\begin{array}{l}\text { Dummy }=1 \text { if respondents used } \\
\text { inorganic fertilizer }\end{array}$ & 57.10 & 38.04 & 60.46 & $22.41 * * *$ \\
\hline Labour demand & Total labour days for farm & 880.82 & 658.99 & 861.09 & $250.79 * * *$ \\
\hline Crop yield & Crop yield (kg/ha) & 7993.39 & 7640.72 & 8055.67 & $414.94 * * *$ \\
\hline Crop income & Crop income (NGN) & 160764.50 & 75754.28 & 175775.90 & $99501.0 * * *$ \\
\hline Agric.Wage income & $\begin{array}{l}\text { Agricultural wage income } \\
\text { employment (NGN) }\end{array}$ & 120861.20 & 90522.83 & 126218.50 & 35695.66 \\
\hline $\begin{array}{l}\text { Self-employment } \\
\text { income }\end{array}$ & $\begin{array}{l}\text { Income from self-employment } \\
\text { (NGN) }\end{array}$ & 103679.40 & 74018.83 & 108917 & $34898.20 *$ \\
\hline Total income & Total household income (NGN) & 376855.30 & 238767.50 & 401239.40 & $162471.9 * * *$ \\
\hline
\end{tabular}

Source: Estimated by Authors

Note: $* * *, * * *$ represent $1 \%, 5 \%$ and $10 \%$ significant levels respectively

Table 2: Gender disaggregated crop diversification index

Gender of household Crop diversification Standard Difference T-value

\begin{tabular}{|c|c|c|c|c|}
\hline head & index & error & & \\
\hline Male & 0.4376 & 0.0045 & $0.102 * * *$ & 8.6387 \\
\hline Female & 0.3356 & 0.0087 & & \\
\hline Pooled & 0.4236 & 0.0041 & & \\
\hline
\end{tabular}

Source: Estimated by Authors

Note; $* * *$ represents $1 \%$ significant level

Table 3: Tobit estimates of the determinants of crop diversification

\begin{tabular}{|c|c|c|c|c|c|c|}
\hline \multirow[t]{2}{*}{ Variable } & \multirow{2}{*}{$\begin{array}{l}\text { Pooled Data } \\
\text { Coeff. }\end{array}$} & \multirow[b]{2}{*}{ Std. Error } & \multicolumn{2}{|l|}{ MHH } & \multicolumn{2}{|l|}{$\mathrm{FHH}$} \\
\hline & & & Coeff. & Std. Error & Coeff. & Std. Error \\
\hline$\overline{\text { Age }}$ & $-0.002 * *$ & 0.001 & $-0.002 * * *$ & 0.000 & -0.004 & 0.003 \\
\hline Extension contact & 0.031 & 0.023 & 0.035 & 0.023 & -0.056 & 0.169 \\
\hline Education & -0.004 & 0.003 & -0.003 & 0.002 & -0.005 & 0.013 \\
\hline Household size & $0.007 * * *$ & 0.002 & $.007 * * *$ & 0.003 & 0.002 & 0.011 \\
\hline Sex & $-0.116^{* * *}$ & 0.025 & & & & \\
\hline Credit access & -0.094 & 0.019 & -0.110 & .02017 & 0.026 & 0.072 \\
\hline Total income & $3.18 \mathrm{e}^{-08^{* *}}$ & $1.44 \mathrm{e}-08$ & $-3.17 e^{-08^{* *}}$ & $1.44^{\mathrm{e}-08}$ & $-1.07 \mathrm{e}-08$ & $6.73 e-08$ \\
\hline Commercialization & $0.201 * * *$ & 0.030 & $-0.204 * * *$ & 0.032 & $-0.238 * *$ & 0.124 \\
\hline Production expenses & $-7.90 \mathrm{e}-08$ & $5.69 \mathrm{e}-08$ & $-8.59 \mathrm{e}-08$ & $5.69^{\mathrm{e}-08}$ & $3.05 \mathrm{e}-08$ & $3.27 \mathrm{e}-07$ \\
\hline Crop income & $2.41 \mathrm{e}^{-07 * * *}$ & $4.61 \mathrm{e}-08$ & $2.40 \mathrm{e}^{-07 * * *}$ & $4.57^{\mathrm{e}-08}$ & $1.63 \mathrm{e}-07$ & $2.86 \mathrm{e}-07$ \\
\hline Self-employment & $3.75 \mathrm{e}-09$ & $3.82 \mathrm{e}-08$ & $8.99 \mathrm{e}-09$ & $3.84^{\mathrm{e}-08}$ & $-1.37 \mathrm{e}-07$ & $1.83 \mathrm{e}-07$ \\
\hline Ag. wage income & $-7.20 \mathrm{e}-06$ & $8.81 \mathrm{e}-06$ & $-4.90 \mathrm{e}-06$ & $9.02^{\mathrm{e}-06}$ & $-1.37 \mathrm{e}-07$ & $1.83 \mathrm{e}-07$ \\
\hline Farm size & $0.043 * * *$ & 0.005 & $0.041 * * *$ & 0.005 & $0.093 * *$ & 0.045 \\
\hline Total labour & $5.12 \mathrm{e}-06$ & 0.000 & $3.81 \mathrm{e}-06$ & 0.000 & 0.000 & 0.000 \\
\hline Inorganic fertilizer & $0.034 * *$ & 0.016 & $0.052 * * *$ & 0.017 & $-0.135 * *$ & 0.066 \\
\hline Improved seed & -0.009 & .021 & -0.008 & 0.021 & -0.008 & 0.021 \\
\hline Crop yield & $1.56 \mathrm{e}^{-06^{* * *}}$ & $5.46 \mathrm{e}-07$ & $1.10^{\mathrm{e}-06^{* *}}$ & $5.62^{\mathrm{e}-07}$ & $5.19 \mathrm{e}-06$ & $2.23 \mathrm{e}-06$ \\
\hline Constant & $0.458 * * *$ & 0.043 & 0.449 & 0.042 & 0.392 & 0.218 \\
\hline Prob $>$ chi $^{2}$ & 0.000 & & 0.000 & & 0.0518 & \\
\hline LR Chi²(17) & 309.20 & & 309.20 & & 24.86 & \\
\hline Log likelihood & -407.02 & & -306.99 & & -84.17 & \\
\hline Pseudo $\mathrm{R}^{2}$ & 0.4753 & & 0.3734 & & 0.3287 & \\
\hline
\end{tabular}

Source: Estimated by Authors

$* * *, * *, *$ represent $1 \%, 5 \%$ and $10 \%$ significant levels respectively 
Table 4: Household's dietary diversity by gender

\begin{tabular}{lrrrr}
\hline $\begin{array}{l}\text { Gender of household } \\
\text { head }\end{array}$ & $\begin{array}{r}\text { Dietary } \\
\text { Diversity }\end{array}$ & Std. Error & Difference & T-value \\
\hline Male-headed & .6995677 & .1644632 & $0.055^{* * *}$ & 4.238 \\
Female-headed & .7549819 & .1578187 & & \\
Pooled & .7078912 & .1646152 & & \\
\hline
\end{tabular}

Source: Estimated by Authors

Note: $* * *, * * *$ represent $1 \%, 5 \%$ and $10 \%$ significant levels respectively

The Tobit estimates further explained that crop diversification among other factors such as sex, credit access, non-farm income, cultivation of improved seeds and extent of commercialization have significant positive correlations with households' dietary diversity as indicated in Table 5. On the other hand, age and use of inorganic fertilizer have negative correlation with dietary diversity of farming households in rural Nigeria. Crop diversification increases the diversity of food crops that can be consumed by the household. Crop diversification was found to significantly $(\mathrm{P}<0.01)$ increase dietary diversity by 0.217 . This result is consistent with similar findings of Pellegrinni and Tasciotti (2014), Makate et.al. (2016) and Mango et al. (2018) which found out that $\mathrm{CD}$ increases $\mathrm{DD}$, especially in the developing countries. Crop diversification have positive correlation with DD in the gender-disaggregated results for both MHHs and FHHs, however, gender differences are observed in the factors influencing households' DD. Tobit estimates presented in Table 5 found that extension services, credit access, commercialization, selfemployment, agricultural wage income, use of inorganic fertilizers and improved seeds significantly influence DD among MHHs but farm size, credit access and CD significantly influenced DD among the FHHs. Crop yield (a proxy for productivity) has positive correlation with DD in both gender groups though not significant. This also supports previous findings of Bouis (2007) that there is positive correlation between nutrition improvement and household's agricultural productivity.

A significant reduction in dietary diversity was obtained in male-headed households which agrees with Taruvinga, Muchenje and Mushinje (2013) that maleheadship would have negative correlation with household's DD. Credit has positive and significant coefficient at $1 \%$. Credit improves household financial capacity to purchase productivity-enhancing inputs and to smoothing consumption. More so, households with credit access are opportune to invest in off-farm activities/enterprises that could increase households' incomes. This is in line with Mango et al. (2018) which noted better income enhances access to varieties of food, hence there was a positive influence of credit on dietary diversity in Central Malawi. The extent of commercialization was found to significantly increase dietary diversity because improvements in extent of commercialization among farming households will lead to increase in farm income which in return enhances household's economic access to food.

\section{Gender differentials in agricultural productivity}

Gender differences in productivity between MHHs and FHHs in rural Nigeria assist to understand determinants of gender gaps in farm productivity and controlling for the variations. The study explains the productivity gap due to variations in characteristics of both genders and due to discrimination against women. The results of the OaxacaBlinder decomposition revealed existence of gender productivity gaps in Nigerian food crop agricultural production as shown in Table 6. These results follow previous studies by Kilic et al. (2013) in Malawi; Aguilar et al. (2013) in Ethiopia, Oseni et al. (2014) in Nigeria, and Mukasa and Salami (2015) in Nigeria, Tanzania and Uganda. Observed factors responsible for the gender gaps were further investigated with policy implications on reduction or closing of gender gaps.

Gender productivity differentials of $10.87 \%$ was obtained which is a lower gap compared to results of previous studies. For instance, Oseni et al. (2014) estimated gender productivity gap of $28 \%$ and $23.9 \%$ in Northern and Southern Nigeria respectively based on LSMS-ISA data of 2010/11 while Mukasa and Salami (2015) estimated a gap of $18.6 \%$ in Nigeria based on LSMS-ISA 2012/2013 data. These estimates revealed the existence of gender productivity gap in Nigeria which is common to African agriculture whereby female farmers are less productive compared with their male counterparts (Kilic et al., 2013; Aguilar et al., 2014). Furthermore, the study considers the sources of productivity gap and their contributions to overall gender differentials. The OB decomposition results revealed that discrimination explains 0.46 points of the lower productivity of female compared with male while endowment reasons 0.42 points of the lower productivity of female farmers compared with their male counterparts. The relative contribution of the sources of gaps to the estimated gender productivity differentials shows that more of the productivity differentials are attributed to discrimination. The endowment effect and the structural effect (discrimination) are of opposite signs. The percentage of the productivity differentials attributed to the differences in the level of observables between male and female farmers (endowment effect) was found to be responsible for $384.82 \%$ (negative) of the total gender gap while the share of the gap attributed to the returns of the observables (discrimination/ structural effect) was $430.81 \%$. Therefore, there is discrimination or structural advantage in favour of male farmers over female farmers. Improvement in endowments, however, will benefit female farmers more than their male counterparts. The interaction of endowments and discrimination was found to favour male farmers over female farmers. 
Table 5: Tobit estimates of correlates of household's dietary diversity

\begin{tabular}{|c|c|c|c|c|c|c|}
\hline \multirow[t]{2}{*}{ Variable } & \multicolumn{2}{|l|}{ Pooled } & \multicolumn{2}{|l|}{ MHH } & \multicolumn{2}{|l|}{ FHH } \\
\hline & Coeff. & Std. Error & Coeff. & Std. Error & Coeff. & Std. Error \\
\hline$\overline{\text { Age }}$ & $-0.000 * *$ & 0.000 & 0.000 & 0.000 & 0.001 & 0.001 \\
\hline Extension contact & $0.033 * * *$ & 0.011 & $0.035 * * *$ & 0.012 & -0.012 & 0.049 \\
\hline Education & 0.002 & 0.001 & 0.001 & 0.001 & -0.001 & 0.003 \\
\hline Household size & -0.001 & 0.001 & -0.001 & 0.001 & 0.002 & 0.003 \\
\hline Sex & $0.029 * *$ & 0.012 & & & & \\
\hline Credit access & $0.092 * * *$ & 0.009 & $0.089 * * *$ & 0.010 & $0.101 * * *$ & 0.022 \\
\hline Total income & $4.92 \mathrm{e}-09$ & $6.35 \mathrm{e}-09$ & $3.90 \mathrm{e}-09$ & 0.000 & $1.87 \mathrm{e}-08$ & $1.97 \mathrm{e}-08$ \\
\hline Commercialization & $0.060 * * *$ & .0150873 & $0.064 * * *$ & 0.016 & 0.034 & 0.036 \\
\hline Production costs & $-2.09 \mathrm{e}-08$ & $4.14 \mathrm{e}-08$ & $-6.05 e-09$ & $4.32^{\mathrm{e}-08}$ & $4.03 e-08$ & $1.62 \mathrm{e}-07$ \\
\hline Crop income & $9.35 \mathrm{e}-08$ & $7.05 \mathrm{e}-08$ & $8.41 \mathrm{e}-08$ & $7.30^{\mathrm{e}-08}$ & $-4.55 e-08$ & $2.96 \mathrm{e}-07$ \\
\hline Self-employment & $9.18 \mathrm{e}-08 * * *$ & $1.83 \mathrm{e}-08$ & $9.59 \mathrm{e}-08 * * *$ & $1.92^{\mathrm{e}-08}$ & $4.65 \mathrm{e}-08$ & $5.80 \mathrm{e}-08$ \\
\hline Ag. wage income & $5.05 \mathrm{e}-06$ & $4.13 e-06$ & $8.70 \mathrm{e}-06^{*}$ & $4.54^{\mathrm{e}-06}$ & -0.000 & 0.000 \\
\hline Farm size & -0.001 & 0.002 & -0.002 & 0.002 & $-0.052 * * *$ & 0.016 \\
\hline Total labour & $4.94 \mathrm{e}-08$ & $5.13 \mathrm{e}-06$ & $6.72 \mathrm{e}-07$ & $5.39^{\mathrm{e}-06}$ & $6.92 \mathrm{e}-06$ & 0.000 \\
\hline Inorganic fertilizer & $-0.022 * *$ & 0.008 & $-0.020 * *$ & 0.009 & -0.025 & 0.020 \\
\hline Improved seed & $0.020 * *$ & 0.010 & $0.022 * *$ & 0.010 & 0.009 & 0.024 \\
\hline Crop yield & $4.25 \mathrm{e}-07$ & $2.76 \mathrm{e}-07$ & $2.96 \mathrm{e}-07$ & $2.96^{\mathrm{e}-07}$ & $1.01 \mathrm{e}-06$ & $7.57 \mathrm{e}-07$ \\
\hline Crop diversification & $-0.064 * * *$ & 0.021 & $-0.058 * *$ & 0.023 & $-0.121 * *$ & 0.060 \\
\hline Constant & $0.652 * * *$ & 0.024 & $0.652 * * *$ & 0.025 & $0.663 * * *$ & 0.073 \\
\hline Prob $>$ chi $^{2}$ & 0.0000 & & 0.0000 & & 0.0000 & \\
\hline Log likelihood & 690.09 & & 582.89 & & 123.18 & \\
\hline Pseudo $\mathrm{R}^{2}$ & -0.4592 & & -0.4459 & & -0.3855 & \\
\hline
\end{tabular}

Source: Estimated by Authors

Note: $* * *, * * *$ represent $1 \%, 5 \%$ and $10 \%$ significant levels respectively

Table 6: Gendered decomposition of sources of productivity gaps and their contributions

\begin{tabular}{|c|c|c|c|}
\hline Gender differentials & Male & Female & Gap \\
\hline \multirow[t]{2}{*}{ Mean productivity } & $7.879 * * *$ & $7.770 * * *$ & $0.108^{*}$ \\
\hline & $(0.048)$ & $(0.124)$ & $(0.056)$ \\
\hline Aggregate Decomposition & Endowment effect & Structural effect & Interaction effect \\
\hline \multirow[t]{2}{*}{ Total } & $-0.418 * *$ & $0.468 * *$ & 0.103 \\
\hline & $(0.198)$ & $(0.209)$ & $(0.139)$ \\
\hline Share of total gender gap & $-384.82 \%$ & $430.81 \%$ & $94.39 \%$ \\
\hline \multicolumn{4}{|l|}{ Detailed Decomposition } \\
\hline \multirow[t]{2}{*}{ Age } & 0.778 & 0.755 & -0.080 \\
\hline & $(0.077)$ & $(0.745)$ & $(0.079)$ \\
\hline \multirow[t]{2}{*}{ Extension Contacts } & -0.081 & 0.047 & $0.149 *$ \\
\hline & $(0.074)$ & $(0.029)$ & $(0.078)$ \\
\hline \multirow[t]{2}{*}{ Household size } & 0.034 & 0.105 & 0.048 \\
\hline & $(0.112)$ & $(0.254)$ & $(0.117)$ \\
\hline \multirow[t]{2}{*}{ Land size } & $-0.603 * * *$ & 0.163 & $0.348 * *$ \\
\hline & $(0.164)$ & $0.077)$ & $(0.163)$ \\
\hline \multirow[t]{2}{*}{ Labour } & 0.062 & 0.093 & -0.035 \\
\hline & $(0.035)$ & $(0.144)$ & $(0.055)$ \\
\hline \multirow[t]{2}{*}{ Crop diversification } & 0.157 & -0.187 & -0.067 \\
\hline & $(0.098)$ & $(0.282)$ & $(0.102)$ \\
\hline \multirow[t]{2}{*}{ Fertilizer } & -0.001 & 0.114 & 0.028 \\
\hline & $(0.010)$ & $(0.051)$ & $(0.028)$ \\
\hline \multirow[t]{2}{*}{ Improved seed } & -0.003 & 0.062 & 0.013 \\
\hline & $(0.012)$ & $(0.056)$ & $(0.016)$ \\
\hline \multirow[t]{2}{*}{ Credit access } & $-0.062 *$ & $-0.267 * *$ & $0.062 *$ \\
\hline & $(0.036)$ & $(0.097)$ & $(0.037)$ \\
\hline
\end{tabular}

Source: Estimated by Authors

Note: Figures in parentheses are standard errors

$* * *, * *, *$ represent $1 \%, 5 \%$ and $10 \%$ significant levels respectively. 
Table 7: Estimates of Oaxaca-Blinder Productivity Decomposition

\begin{tabular}{lll}
\hline Productivity Decomposition components & Males & Females \\
\hline Mean land productivity (kg/ha) & 8055.67 & 7640.72 \\
Productivity gap (kg/ha) & 414.94 & \\
Endowment effect & & -1596.39 \\
Discrimination effect & & 1788.02 \\
Productivity without discrimination & & 9428.74 \\
\hline
\end{tabular}

Source: Estimated by Authors

Further insights revealed detailed decomposition of sources of gender gap in Table 6 which explains the contribution of different factors to the sources of gender gap. A positive coefficient widens the gap while a negative coefficient reduces the gender gap. The endowment effect was explained by the difference in land size between male and female farmers. Land was a major factor with the highest contribution (negative) to endowment effect, reducing the gap. Credit access has significant negative contribution to the endowment effect, accounting for $14.83 \%$ of the total endowment effect. This reveals that improvement in women's endowments in terms of access to land and credit facilities is very strong in closing gender productivity gap in Nigeria. Quantity of fertilizer has significant positive contribution to the structural disadvantage, thereby widening gender gap. This affects the magnitude of structural effects on male farmers' productivity. Access to credit further has significant negative relationship for female structural disadvantage which tend to generate higher returns in agriculture for women than men, thus result into a strong structural effect on female farmers' productivity.

Given characteristics of the female farmers, model estimates explained that without discrimination against women, their land productivity should be $9428.74 \mathrm{~kg} / \mathrm{ha}$ as expressed in Table 7. This implies that due to discrimination, female farmers recorded $1,788.02 \mathrm{~kg} / \mathrm{ha}$ less than male farmers. The value of discrimination represents $23.39 \%$ of their actual productivity.

\section{CONCLUSION}

The study investigated crop diversification, productivity and dietary diversity of male-and female-headed farming households in Nigeria. Male farmers' crop diversification index was 0.10 , significantly higher than female farmers. Diet is more diverse among female-headed than maleheaded households. Crop diversification, sex, credit access, non-farm income, improved seeds cultivation, and extent of commercialization have positive and significant correlation with households' dietary diversity. The study found a presence of gender productivity gap in rural Nigeria due to variations in characteristics of both genders and discrimination against women. The overall gender productivity gap is $10.87 \%$, female farmers are less productive compared to male farmers in rural Nigeria. Discrimination in terms of structural advantages favour male farmers while improved endowments benefits female farmers more than male farmers. Yet, the negative interactions of endowments and discrimination favour male farmers over female farmers in Nigeria. Without discrimination, the productivity of women farmers would increase by $23.39 \%$. Structural disadvantages against women continue to unlock their agricultural productivity potentials. Endowment and structural disadvantages of female farmers in land and credit facilities are key drivers of gender productivity gaps. Policy interventions should focus on factors that enhance crop diversification especially access to land resources and credit facilities as key drivers of dietary diversity and closing gender productivity gaps. Hence, fast-tracking achievement of gender productivity equality, women's empowerment and inclusive agrifood system in Nigeria.

Suggestion for further research: A regular investigation of gender differentials especially at the national level is worth undertaking to ensure achievement of gender equality especially in African agricultural sector.

\section{REFERENCES}

ADESINA, A. (2017). Why is Africa importing $\$ 35$ bn in food annually? AfDB boss asks. Africanews.

ALLIANCE FOR A GREEN REVOLUTION IN AFRICA (AGRA) (2017). Africa agriculture status report: the business of smallholder agriculture in subsaharan Africa. Nairobi, Kenya. Issue No.5 ISSN: 2313-5387. https://agra.org/wpcontent/uploads/2017/09/Final-AASR-2017-Aug28.pdf .

AGUILAR, A., CARRANZA, E., GOLDSTEIN, M., KILIC, T., \& OSENI, G. (2014). Decomposition of gender differentials in agricultural productivity in Ethiopia. The World Bank, Africa Region, Poverty Reduction and Economic Management Unit, Policy Research Working Paper 6764. http://dx.doi.org/10.1596/1813-9450-6764

ALI, D. A., DEININGER, K., \& RONCHI, L. (2015). Costs and benefits of land fragmentation: evidence from Rwanda. World Bank Policy Research Working Paper No. 7290. http://dx.doi.org/10.1596/18139450-7290

BACKINY-YETNA, P., \& MCGEE, K. (2015). Gender differentials and agricultural productivity in Niger. Development Research Group Poverty and Inequality Team, Policy Research Working Paper 7199. http://dx.doi.org/10.1596/1813-9450- 7199

BIZZARI, M. (2017). Gender-Sensitive Social Protection for Zero Hunger, World Food Programme/WFP. Regional Bureau for Latin America and the Caribbean. https://documents.wfp.org/stellent/groups/public/docu ments/liaison_office.

BOUIS, H. E. (2007). The potential of genetically modified food crops to improve human nutrition in developing countries", Journal of Development 
Studies

43.

79-96. http://dx.doi.org/10.1080/00220380601055585.

CHRISTIAENSEN, L., \& DEMERY, L. (2007). Down to earth: Agriculture and poverty reduction in Africa. Washington, DC: The World Bank. http://dx.doi.org/10.1596/978-0-8213-6854-1

CHRISTIAENSEN, L., \& MARTIN, W. (2018). Agriculture, Structural Transformation and Poverty Reduction: Eight New Insights. World Development 109, 413-416. http://dx.doi.org/10.1016/j.worlddev.2018.05.027

DE LA O CAMPOS, A. P., COVARRUBIAS, K. A., \& PATRON, A. P. (2016). How does the choice of the gender indicator affect the analysis of gender differences in agricultural productivity? Evidence from Uganda. World Development,77, 17-33. https://doi.org/10.1016/j.worlddev.2015.08.008.

DE SCHUTTER, O. (2013). Gender Equality and Food Security: Women's Empowerment as a Tool against Hunger, the Food and Agriculture Organisation/FAO, Philippines. http://www.fao.org/wairdocs/ar259e/ar259e.pdf.

DI FALCO S., \& CHAVAS, J. P. (2009). Crop biodiversity, risk exposure and food security in highlands of Ethiopia. American Journal of Agricultural Economics, 9(3), 599-631. http://dx.doi.org/10.1111/j.1467-8276.2009.01265.x

DOROSH, P AND THURLOW, J (2016). Beyond agriculture versus non-agriculture: decomposing sectoral growth-poverty linkages in five African countries. World Development, 109,440-451. https://doi.org/10.1016/j.worlddev.2016.08.014.

DUBE, L. (2016). Factors influencing smallholder crop diversification: a case study of Manicaland and Masvingo provinces in Zimbabwe. International Journal of Regional Development, 3(2), 1-25. ISSN 2373-9851.

http://www.macrothink.org/journal/index.php/ijrd/arti cle/view/9194

FAO (Food and Agriculture Organization of United Nations). (2011). Guidelines for measuring household and individual dietary diversity. http://www.fao.org/fileadmin/user_upload/wa_works hop/docs/FAO-guidelines-dietary-diversity2011.pdf

FAO, IFAD, UNICEF, WFP \& WHO. (2017). The state of food security and nutrition in the world 2017. Building resilience for peace and food security. Rome. http://www.fao.org/3/a-I7695e.pdf .

GIROUD, A., \& HUAMAN, J.S. (2016). Investment in agriculture and gender equality in developing countries. Transnational Corporations, 26(3), 89. http://dx.doi.org/10.18356/e7a807e6-en.

GEBRE, G. G., ISODA, H., RAHUT, B. D., AMEKAWA, Y., \& NOMURA, H. (2019). Gender Differences in Agricultural Productivity: Evidence from Maize farm households in southern Ethiopia. GeoJournal. http://dx.doi.org/10.1007/s10708-01910098-y.

HERRERO, M., THORNTON, P. K., POWER, B., BOGARD, J., REMANS, R., FRITZ, S., \& HAVLIK, P. (2017). Farming and the geography of nutrient production for human use: a transdisciplinary analysis.
Lancet Planet Health, 1(1), 33-42. http://dx.doi.org/10.1016/S2542-5196(17)30007-4.

IFPRI (2019). Achieving agricultural sustainability depends on gender equality. IFPRI Headquarters, Washington, DC 20005-3915 USA. https://www.ifpri.org/blog/achieving-agriculturalsustainability-depends-gender-equality.

IJIEH, S. O., ESHENAKE, B., \& AZU, B. (2015). Gender inequality in agriculture: a tool for sustainable economic growth. Research on Humanities and Social Sciences, 5(21), 49-53. ISSN (Paper) 2224-5766 ISSN (Online) 2225-0484 (Online).

JIRSTROM, M., ANDERSSON, A., \& DJURFELDT, G. (2011). Smallholders caught in poverty-flickering signs in agricultural dynamism. In G. Djurfeldt, E. Aryeetey, \& A. Isinika (Eds.), African smallholders: Food crops,markets and policy 74-106. Wallingford, Oxford: CABI.

KILIC, T., PALACIOS-LOPEZ, A., \& GOLDSTEIN, M. (2013). Caught in a productivity trap: a distributional perspective on gender differences in Malawian Agriculture. Policy Research Paper No. 6381, The World Bank https://doi.org/10.1596/1813-9450-6381

LIN, B. B. (2011). Resilience in agriculture through crop diversifcation: adaptive management for environmental change. Bioscience, 61(3):183-93. http://dx.doi.org/10.1525/bio.2011.61.3.4.

LLOYD, C. B., \& GAGE-BRANDON, A. J. (1993). Women's role in maintaining households family welfare and sexual inequality in Ghana. Population Studies, $\quad 47(1): 115-131$. http://dx.doi.org/10.1080/0032472031000146766.

MAKATE, C., WANG, R., MAKATE, M., \& MANGO, N. (2016). Crop diversification and livelihoods of smallholder farmers in Zimbabwe: adaptive management for environmental change. SpringerPlus, 5(1):1-18. https://doi.org/10.1186/s40064-016-28024

MANNGO, N., MAKATE, C., MAPEMBA, L., \& SOPO, M. (2018). The role of crop diversification in improving household food security in central Malawi. Agriculture \& Food Security, 7(7): 1-10, https://doi.org/10.1186/s40066-018-0160-X .

MCDONALD, J. F., \& MOFFIT, R .A. (1980). The uses of Tobit analysis. Review of Economics Statistics, 61(2), 318-327. http://dx.doi.org/10.2307/1924766

MUKASA, A. N., \& SALAMI, A.O. (2015). Gender productivity differentials among smallholder farmers in Africa: a cross-country comparison. Working Paper Series No. 231, African Development Bank, Abidjan, Côte d'Ivoire

MUKASA, A. N., \& SALAMI, A. O. (2016). Gender equality in agriculture: What are really the benefits for sub-Saharan Africa? Africa Economic Brief, 7(3). https://www.afdb.org/fileadmin/uploads/afdb/Docum ents/Publications/AEB Vol_7_Issue 3_Gender_equa lity in agriculture.pdf

NJERU, E. M. (2013). Crop diversification: a potential strategy to mitigate food insecurity by smallholders in SSA. Journal of Agric. Food System Community, 3(4), 63-69. https://doi.org/10.5304/jafscd.2013.034.006. 
OJO, M. A., OJO, A. O., ODINE, E., \& OGAJI, A. (2014). Determinants of crop diversification among smallscale food crop farmers in north central, Nigeria. PAT 10(2), 1-11.

OSENI, G., CORRAL, P., GOLDSTEIN, M., \& WINTERS, P. (2015). Explaining gender differentials in agricultural production in Nigeria. Agricultural Economics, 46(3), 285-310. http://dx.doi.org/10.1111/agec.12166.

PELLEGRINI, L., \& TASCIOTTI, L. (2014). Crop diversification, dietary diversity and agricultural income: empirical evidence from eight developing countries. Canadian Journal of Development Studies, $35(2), \quad 211-227 . \quad$ https://doi.org/ 10.1080 /02255189.2014.898580.

RAHMAN, S., \& CHIMA, C.H. (2016). Determinants of food crop diversity and profitability in southeastern Nigeria: a multivariate Tobit approach. Agriculture, MDPI, 6(2), 1-14. http://dx.doi.org/ 10.3390/ agriculture 6020014 .

SICHOONGWE, K., MAPEMBA, L, TEMBO, G., \& NG'ONG'OLA, D. (2014). The determinants and extent of crop diversification among smallholder farmers: a case study of southern province Zambia. Journal of Agricultural Science; 6(11), 150-159. ISSN 1916-9752. http://dx.doi.org/10.5539/jas.v6n11p150 